\title{
GREEN ECONOMY READINESS IN SOUTH AFRICA: A FOCUS ON THE NATIONAL SPHERE OF GOVERNMENT
}

\author{
Godwell Nhamo: Exxaro Chair in Business and Climate Change Institute for Corporate Citizenship \\ University of South Africa nhamog@unisa.ac.za
}

\begin{abstract}
Readiness! This is a concept interchanged with preparedness and, many assume, adequate knowledge. Simple as it may be, readiness denotes a complex interaction of parameters and conditionalities required for an uptake of a phenomenon - in the context of this article, green economy transition. Following deliberations to and from Rio+20, there is no doubt the world is set to undertake green economy as a means to attaining sustainable development, poverty eradication, job creation and equity evermore. At the heart of the green economy is the need to address negative impacts associated with one of the key global challenges of our epoch, climate change. The question this article seeks to address is: To what extent is South Africa green economy ready? Focusing on the national sphere of government, the article concludes that this country has moved swiftly in addressing key readiness parameters, including high-level commitment and stakeholder buy-in, enhancing institutional set-up, developing the necessary legislation, establishing funding mechanisms and having programmes running on the ground. However, more work is still needed in areas such as continued domestication of the understanding on green economy, addressing weak individual and institutional capacity, increasing funding, proliferation of policies, matching national to global interests on green economy, and the role of higher (including further) education.
\end{abstract}

Keywords: finance; green economy; institutions; legislation; readiness; South Africa; technology

\section{Introduction}

There is now considerable literature dealing with the notion of green economy, and its interchangeable concepts such as green growth, transition to a green economy, greener economies and inclusive green growth, etc (AU 2012; Deloitte 2012; GEC 2011; OECD 2012a; UNEP 2011). In the literature readers will find sub-components of green economy, such as low carbon economy, climate-resilient growth, clean technology economy, transition to low carbon economy, climate compatible development, etc. As will be discussed in greater depth here, the author uses green economy and green growth interchangeably. When considering readiness, it is paramount to note that this is not an event but rather a process aligned to procedures and protocols. Hence, green economy readiness may span across historical periods, including how governments and other entities have been addressing the broader pillars of sustainable development, namely environmental, social and economic sustainability.

This author is of the opinion that governments and organisations that are found to be green economy ready are those that have invested considerable resources to address the key pillars of sustainable development. Such governments have environmental and other social aspects engraved in their constitutions, they have environmental management or conservation acts in place, along with sustainable development strategies, skills development policies and acts, biodiversity and air pollution acts, water acts, and many more. Such conformity may be considered to constitute firstorder green economy readiness. Second-order green economy readiness sees governments and entities put in place targeted measures to address specific dictates of the new green economy, in the context of sustainable development and poverty eradication. Here lies the main focus of this 
article. In the first-order green economy readiness realm, governments and organisation ensure that parameters not necessarily directly linked to green economy readiness are in place. Such parameters include operating efficiency and effectiveness, infrastructure (roads, rail and air networks), human capital, good governance and accountability, anti-corruption measures, electricity grids servicing the hinterlands, well- functioning industries, a good investment climate, operational information technology, constructive media, educational institutions which channel high-quality graduates, etc. From such a base, second-order green economy readiness is likely to flow easily.

What, then, is readiness? This is a phenomenon most of us encounter on a regular basis. Think of the early morning rush to get to school, work or any other activity. It implies getting ready to go: waking up, bathing, getting dressed, catching transport. In a similar way, toddlers are not sent to school before they are school ready, and underage children are not yet considered eligible to marry. Farmers prepare their land for planting and when crops are ready they harvest. Fishermen prepare their lines boats, nets, etc before embarking on what they know best - fishing. Hence, conditions of minimum readiness must be met. Athletes do not go to sports meets unprepared: they do regulartraining, register for the competition, eat healthy foods, wear appropriate gear - all of which are readiness activities. No couch-potato tackles the Comrades Marathon on a whim. The key point is: there are readiness conditions. As highlighted earlier, this article narrows these down to green economy readiness in South Africa, taking stock and mapping the road ahead at the national sphere of government. The next section of this article deliberates on climate change in green economy readiness discourses. This is followed by a focus on green economy as a means or an end in itself. The next section deliberates on theoretical perspectives on green economy readiness. This is followed by a focus on green economy readiness in South Africa and subsequent action points for the future.

\section{Methodological underpinnings}

This article addresses a single main research question: To what extent is South Africa green economy ready? The methodology follows seven phases: 1) an intensive literature survey of green economy readiness work; 2) designing a green economy readiness framework based on emerging readiness fundamentals from the literature survey; 3 ) pilot testing of the green economy readiness framework brief reconnaissance questionnaire with selected experts in the field and emailing 100 questionnaires; 4) experts' perceptions survey; 5) analysis of the experts' perceptions survey; 6) further intensive South African policy-oriented document review, to trace emerging themes from the experts' perceptions survey; and 7) further analysis and conclusions based on the research premises. A total of 32 questionnaires were received back, with six excluded from the analysis due to validity concerns (missing variables, etc.). The final sample from the expert survey consisted of 26 questionnaires.

\section{Climate change in green economy readiness discourses}

It will be an incomplete story if climate change is not considered when discussing green economy readiness. At the interface of the green economy are discourses on major global crises (financial, energy and climate change). In this section, one such crisis dominating deliberations on the green economy and sustainable development, namely climate change, is briefly discussed with the main purpose of showing empirical evidence of trends, as portrayed through natural disasters such as droughts, extreme temperatures, floods and storms. No space will be devoted to debating whether or not climate change is taking place, as these are the debates of old. The urgency for a need to address climate change may be best informed by reading the global trends shown in Figure 1 . The global position, to limit temperature rise to within two degrees Celsius above pre-industrial levels, must always inform current and future decisions (Polycarp et al. 2013). Using data from a globally recognised source, the EM-DAT, the findings reveal that natural disaster trends globally show a 
sharp upward trend. The evidence of climate change is so shocking that it calls humanity to urgently do something, from the perspectives of climate change mitigation (i.e., reduce greenhouse gases emitted into the atmosphere) and adaptation (i.e., develop technologies and methodologies that allow humanity to live side by side with the changing climate).

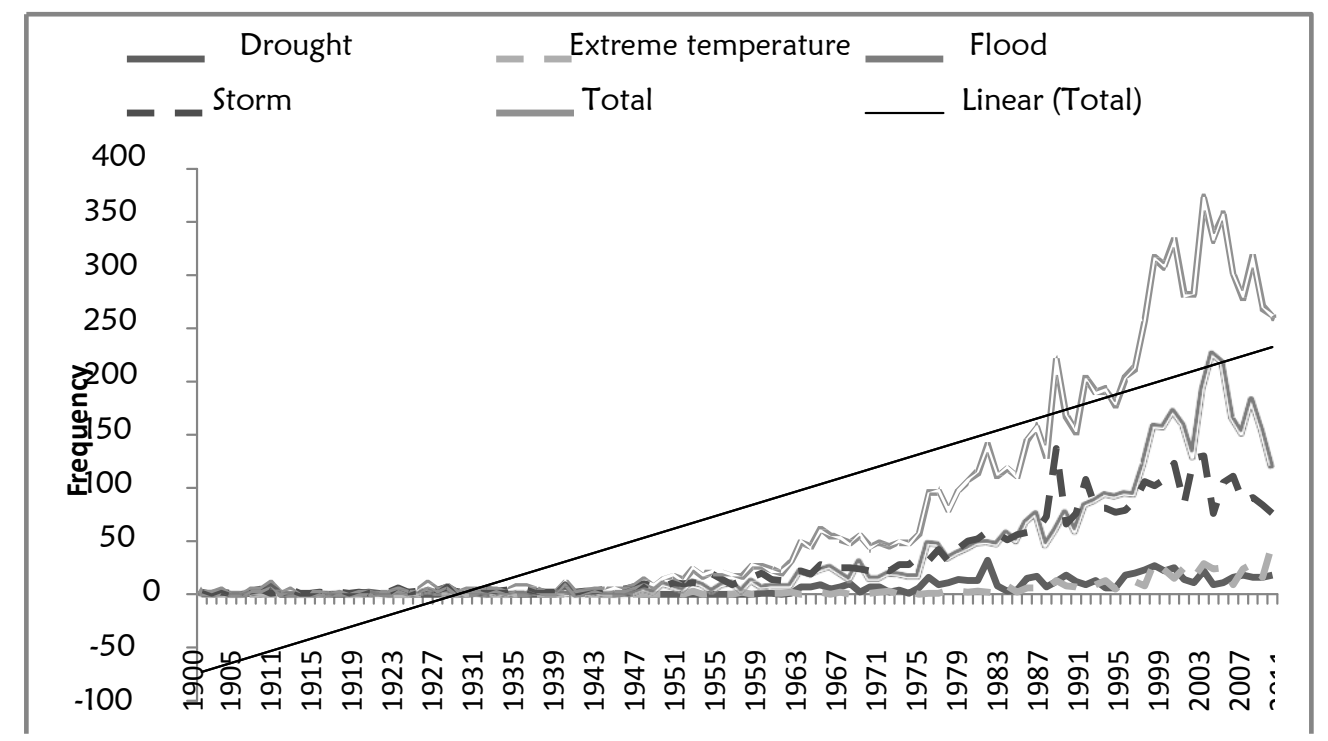

Figure 1: Global trends in selected natural disasters (1900-2012)

Source: Author (data from www.emdat.be)

Globally, only four natural disasters (drawn from droughts, extreme temperatures, floods and storms) were recorded in 1900 and such disasters peaked at 374 in 2005. Similar recorded high frequency events include: 310 disasters in 2001, 335 each in 2002 and 2006, 359 in 2007, 302 in 2008 and 319 in 2010.

\section{Green economy: A means or an end in itself?}

The concept of means and ends is often debated in many fora. Sen (2013) addresses it within the sustainability (desired end) and sustainable development (means to sustainability) discourse. In those contexts the author brings up the notion of capabilities. Rauschmayer and Lessmann (2013) acknowledge how debates around the sustainability concept moved away from 'needs' to either 'freedoms' or 'capabilities'. From an academic perspective, green economy can be viewed both as a means to an end and an end in itself. This is contrary to the world-wide political view and understanding that came out of Rio +20 . Rio +20 treated green economy as a means to achieving sustainable development and poverty eradication. This is part of the future global leaders said they wanted from Rio+20. 
In a typical consideration of green economy as an end in itself, the Climate and Development Knowledge Network (CDKN) (2011) raises five first- tier potential target outcomes for green growth (see Figure 2). Second-tier potential target outcomes for a green economy include lower greenhouse gas emissions, economic growth and human development, poverty reduction, enhanced biodiversity and ecosystems services, and climate change resilience. Both sets of potential target outcomes are a perfect match for what sustainable development aims to achieve.

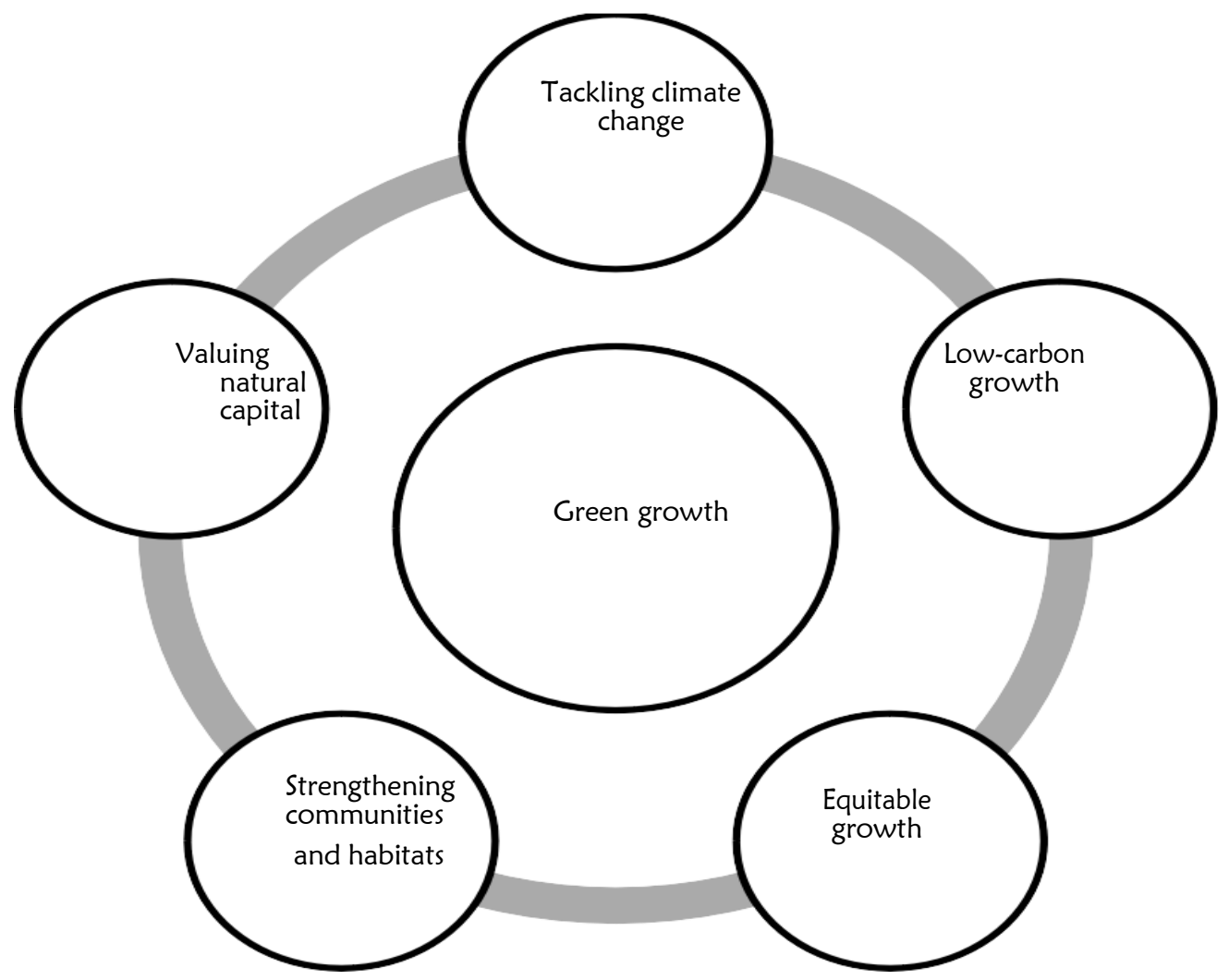

Figure 2: Potential target outcomes for green growth

Source: CDKN $(2011,2)$

Although it is difficult to define complex concepts, authors seemingly have not learnt much from the historical conceptualisation of sustainable development, hence the emergence of numerous definitions of the concept of 'green economy'. The most commonly cited definition is provided by the United Nations Environment Programme (UNEP) (2011a, 1):

[It] results in improved human well-being and social equity, while significantly reducing environmental risks and ecological scarcities. In its simplest expression, a green economy can be thought of as one which is low carbon, resource efficient and socially inclusive. In a green economy, growth in income and employment should be driven by public and private investments that reduce carbon emissions and pollution, enhance energy and resource efficiency, and prevent the loss of biodiversity and ecosystem services. 
The Green Economy Coalition (GEC) $(2011,3)$ maintains:

A green economy is about a different way of doing things. It is about recognising that our economies need to be guided by different goals, they need to be sustained by different activities, and they need to deliver different results.

Wapner $(2011,525)$ addresses the role of civil society in producing societies working towards a fair, just and green future. In his view, it is imperative that consensus be reached on the definition of what constitutes a green economy. A green economy therefore is one that 'ensures fair use of ecological resources and sinks at re-generational and bio- assimilation rates' (ibid.). In the transition to such an economy, fundamentals addressing full cost accounting, closed waste loops, sustainable ethics, progressive green taxes and enhanced environmental health are necessary building blocks. This must be done knowing full well, in Wapner's words, that 'the rich rule the world' and more often, civil society is the tail being waged by the economic dog. The African Development Bank (AfDB) (2012. 5) investigated the concept of green growth within an African context and defines it thus:

Pursuing inclusive economic growth through policies, programmes and projects that invest in sustainable infrastructure, better manage natural resources, build resilience to natural disasters and enhance food security.

To promote green growth, the African continent needs to work on enhancing the political will to come up with shared visions. Countries need to focus on what matters - economic development. In addition, there is a need to plan for the future, send the right messages to the private sector, and finance green growth. Although a number of sources could fund green growth, budgetary support is critical, especially as regards readiness expenditure. Some elements of readiness such as policy, institutional capacity, functional grids and communication infrastructure might not attract external funding, and governments need to contribute in preparation for potential investments linked to such conditionalities. Due to lack of consensus on terminology, the International Chamber of Commerce (ICC) prefers using the concept 'greener economies', which it believes acknowledges that there are many challenges and opportunities across sector and value chains (ICC 2011). In line with Rio+20 deliberations on green economy in the context of sustainable development, the ICC $(2011,2)$ came with yet another definition: 'An economy in which economic growth and environmental responsibility work together in a mutually reinforcing fashion while supporting progress on social development.' In response to other terminology used interchangeably with green economy, the ICC identified green growth, which it views as an operational and process level bottom-up approach, while green economy is predominantly top-down and witnessed at strategic and systems levels. Najam and Selin (2011) strongly feel that issues of equity and human wellbeing must be central to green growth. In the quest to better understand the green economy, questions are being raised regarding the blue economy - an issue which small island developing states (SIDS) find more relevant today in the context of climate change. This has resulted in UNEP undertaking major research on the topic, culminating in the report: A green economy in a blue world (UNEP 2012a, 3). UNEP observes that 'a worldwide transition to a low-carbon, resourceefficient green economy will not be possible unless the seas and oceans are a key part of these urgently needed transformations'. SIDS are particularly vulnerable to environmental and natural disasters given their environmental fragility and their limited ecosystems, financial resources and human capital. Sea level-rises remain a reality, and any disturbances in the economic and natural environment may curtail tourist arrivals, one of the main economic activities in SIDS. Tourism alone represents more than 30 per cent of total income from the export sector in SIDS (UNEP 2012a).

What, then, constitutes a green economy or green growth? Cadogan-Cowper and Johnson (2011, 3) of the Australian Bureau of Statistics highlight the move towards the desired consensus by summarising the green economy as focusing on

- investing in cleaner energy, 
- investing in natural resource efficient technologies and products,

- sustainable use of natural resources,

- repair and maintenance of natural ecosystems, and

- enabling policy settings, including the regulatory environment, taxation and subsidies.

To the list above, this author adds that in an African context, a green economy must show inherent bias towards the climate change adaptation agenda. Hence, while the mitigation agenda must be treated with urgency, the adaptation agenda seems more urgent than ever. A green economy must also continue to emphasise the central role of education in general (at all levels: pre-primary, primary, secondary and tertiary), education for sustainable development and climate change education in particular, in realising the broader sustainability focus. In this realm of understanding, global leaders (and more so African leaders) are right to consider the green economy within the context of sustainable development, as confirmed during Rio+20. The call therefore will be to continue searching and identifying the relationship between the green economy agenda in the broader context of the old agendas of sustainable development, and poverty eradication, equity and job creation.

\section{Theoretical perspectives on green economy readiness}

As indicated earlier, readiness (or preparedness) is not exclusive to the concept of a green economy. Readiness features in other disciplines such as the military, education, ICT, disaster management, agriculture, etc. Closer to the discipline under discussion, one may debate climate finance readiness, REDD+ readiness and other readiness mechanisms, among them green economy readiness. This section features selected cases of readiness, to open up understanding from both generic and specific readiness perspectives. In their work on readiness for scaled-up low-carbon energy investment, Polycarp et al. (2013) focus on policy, institutional, industry and financial conditions. The policy and institutional prerequisites cover plans and targets for low-carbon energy development, while industry conditions focus on the capacity to develop bankable projects. Other necessary conditions under industry include information on renewable energy resource availability, engineering capacity and other infrastructure. With regard to finance, the sector must be mature and stable, with finance readily available for feasible projects which have been identified and proposed. Six case studies involving energy efficiency (Thailand), wind power (South Africa), solar water heating (Tunisia), geothermal power (Indonesia), wind power (Mexico) and energy efficiency (India) have been used to test readiness conditions. Overall, the twin fundamental determinants for scaling up on low-carbon energy emerged as government leadership and effective responses to price distortions. The authors conclude that 'there is no simple approach to supporting readiness activities' (ibid., 10).

South Korea still stands out as a leader in green growth transition. In addressing South Korea's green economy readiness path, Kang et al. (2012) identify three pillars to readiness: regulations to reduce GHG emissions from industries; incentives for businesses to develop green technologies, products and services; and public information tools for awareness and increased demand for green products. Kang et al's findings confirm that South Korea's institutionalisation of the green growth strategy, with its unwavering political commitment plus clear implementation programme, were key to the successful implementation of the green growth transition agenda. Furthermore, the clear definition of roles and responsibilities among social partners (government, private sector, labour, etc.) during planning, budget preparation and implementation, ensured greater success. Such lessons are vital for deliberating on green economy readiness in South Africa and in other developing countries in Africa. Dual Citizen (2012) produced its third National Green Performance Index, for the 27 economies hosting 90 per cent of green economy investments. Among the countries involved are Brazil, Russia, India, China and South Africa (BRICS). The parameters include leadership, policy, clean technology investment and sustainable tourism. Details regarding the weighting are reflected in Figure 3. 


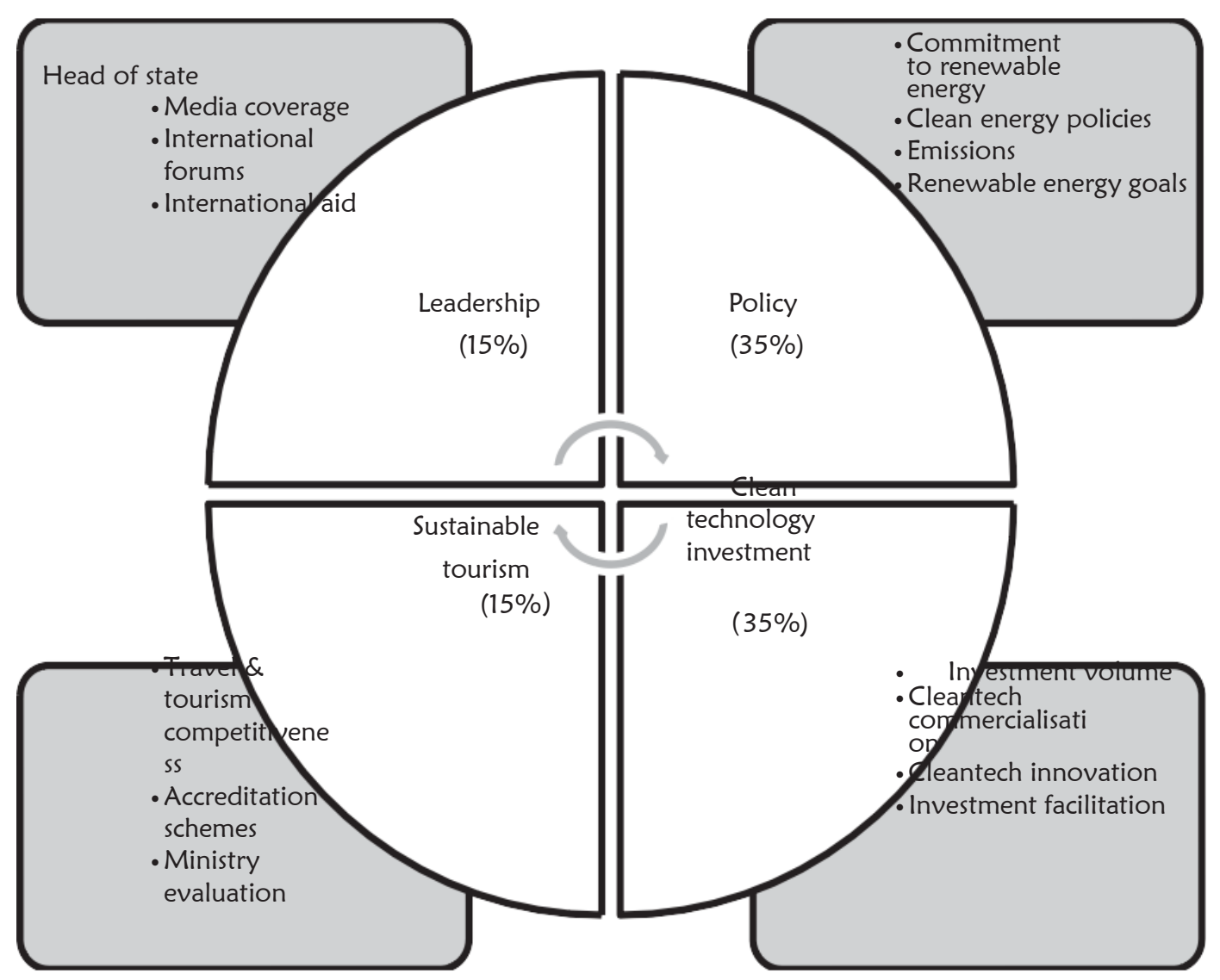

Figure 3: National Green Performance Index parameters Source:

Author, after Dual Citizen $(2012,3)$.

Sub-indicators under the leadership parameter include the head of state's advocacy for green issues, positive media coverage of a national green economy, national positions and statements in international forums, and commitment to sustainability in aid programmes. For the policy parameter, issues such as renewable share of final energy, adoption of best practice policies, national emissions trading and progress towards renewable goals, are considered. Clean technology investments focus on recent investment volumes in clean energy, business climates for clean technology commercialisation and innovation, the strength of green investment and export promotion. Lastly, sustainable tourism measures the country's competitiveness in sustainable tourism, the presence and strength of national schemes, and the strength of green tourism promotion (Dual Citizen 2012). As regards the four parameters, South Africa only features in the top 10 in terms of sustainable tourism, but took a respectable third place after New Zealand and the United Kingdom. 
One might ask: Why the need to be green economy ready? Why do developing economies still need space to emit, in order to grow? These are pertinent questions, given that issues of trade are now fully integral to green economy discourses. Also, many countries of the south are subjected to multi-, bi- and unilateral measures to 'force' them into compliance and green their economies (Melendez-Ortiz 2011). In addition, greening economies equal good environmental stewardship. In fact, this must be the duty of global leadership as a whole. In a policy brief addressing the potential damage of border carbon adjustments (BCA) to the South African exporting sector, Cosbey and Wooders (2011) reveal the negative bilateral impacts BCA may have on the economy. Should BCA regimes be instituted, exports to the European Union (EU) and United States (US), based on the 2009 data, would have cost South Africa $€ 380$ million and US\$210 million respectively. The highest impact would have been felt in the iron and steel industries and the non- ferrous metals sector. Apart from the industries highlighted here, the South African civil aviation industry will be affected by the EU Aviation Directive that became effective on 1 January 2012 as part of the EU Emissions Trading System (EU ETS) under the Kyoto Protocol (Ireland 2012). The directive aims to curtail global civil aviation carbon emissions in the absence of a global consensus on the issue. For South Africa to address this, it might take the longer World Trade Organisation (WTO) route to resolve the dispute, or the shorter route to show that concerted efforts are being made to reduce the inherently high carbon content of said products domestically. The later resonates well with South Africa, as a carbon tax will be introduced in 2015. This was revealed during the 2013 budget speech by Finance Minister Gordhan:

Government proposes to price carbon by way of a carbon tax at the rate of $R 120$ per ton of CO2 equivalent, effective from 1 January 2015. ... An updated carbon tax policy paper will be published for further consultation by the end of March 2013. (Gordhan 2013, 15)

There are a number of rising green economy stars in Africa, such as Mauritius, the Seychelles, Rwanda, Kenya, Mozambique and Ethiopia, which have been preparing to take full advantage of the emerging green economy. In this section, Rwanda is profiled. The country's drive towards green growth centres on Rwanda's Vision 2050, which envisages it as developing a climate-resilient, low-carbon economy by 2050 thanks to the slightly crowded Green Growth and Climate Resilience National Strategy for Climate Change and Low Carbon Development - Green Growth Strategy (Rwanda Ministry of Natural Resources [MINIRENA] 2011). Some of the planned programmes identified include: sustainable land use management; integrated water resource management; climate compatible mining; sustainable forestry, agro forestry and biomass; a low-carbon energy grid and small-scale energy access in rural Rwanda; disaster risk reduction; green industries; a resilient transport system; and low-carbon urban systems. To achieve this, Vision 2050 draws on a readiness framework composed of institutional arrangements; finance; capacity building and knowledge management; technology, innovation and infrastructure; and integrated planning and data management. Overall, Rwanda's transition to a green economy relies on 'big wins, quick wins and further work' (MINIRENA 2011). At the intersection of development, climate change mitigation and climate change adaptation, Rwanda finds its niche in climate-compatible development. At the intersection of climate change mitigation and development, Rwanda envisages low-carbon development. At the intersection of development and climate change adaptation there is climateresilient development, and at the intersection of climate-change adaptation and climate-change mitigation there is climate-resilient carbon reduction.

Ellis et al. (2013) draw attention to the drivers of and challenges facing climate- compatible development, linking these to a readiness framework. Noticeable drivers call for a recognised need at national level to adapt to climate change in order to bolster resilience, achieve growth and reduce poverty; energy security and natural resource efficiency; a desire to capitalise on emerging economic opportunities; improved access to climate finance and aid; and strong government leadership. On the other hand, the challenges brought to the fore include costs associated with change; interest 
groups opposed to change; a lack of awareness; short-termism; inadequate state capacity to respond and implement strategies; institutional constraints; and technological constraints and uncertainties. In a breakthrough report by the Economist Intelligence Unit (2011, 3), Australia's readiness for a low-carbon future was outlined. The report, informed by a survey of more than 130 senior executives, aimed to answer the following questions:

How prepared are Australian corporations for a low-carbon economy? What are the biggest threats posed by Australia's shift to a more sustainable model? What is industry's preferred option for pricing carbon, and why? And, crucially, have Australian firms identified opportunities for growth or alternative markets that are emerging or may emerge from a low-carbon economy?

The major findings were that corporate strategy on carbon reduction was held back by a lack of policy clarity; most Australian firms were doing something to address carbon emissions, although few had detailed strategies for a low-carbon future; firms saw opportunities in a low-carbon future, and action to capitalise on such was underway; the biggest perceived risk was increased costs; there was little corporate consensus on the impact of climate change; the bulk of respondents favoured some sort of carbon-pricing scheme; and bigger companies were better prepared for a lowcarbon Australian future (see Economist Intelligence Unit 2011). In measuring progress towards an inclusive green economy, UNEP (2012b) indentified a set of indicators at the initial, intermediate and final stages. During the initial stages it is necessary to measure progress using indicators for environmental issues and targets. During the intermediate stage indicators for policy interventions can be used, and lastly, during the final stages, indicators for policy impacts on wellbeing and equity can be applied (see Table 1).

Table 1: Illustrative thematic issues for measuring progress towards a green economy

\begin{tabular}{|c|c|c|}
\hline Environmental & Policy & Wellbeing and equity \\
\hline $\begin{array}{ll}\text { - } & \text { Climate change } \\
\text { - } & \text { Ecosystem management } \\
\text { - } & \text { Resource efficiency } \\
\text { - } & \text { Chemicals and waste } \\
& \text { management }\end{array}$ & $\begin{array}{ll}\text { - } & \text { Green investment } \\
\text { - } & \text { Green fiscal reform } \\
\text { - } & \text { Pricing externalities } \\
& \text { and valuing } \\
& \text { ecosystem service } \\
\text { - } & \text { Green procurement } \\
\text { - } & \text { Green job skills } \\
& \text { training }\end{array}$ & $\begin{array}{ll}\text { - } & \text { Employment } \\
\text { - } & \text { Environmental goods and } \\
\text { - } & \text { Torvices sector wealth } \\
\text { - } & \text { Access to resources } \\
\text { - } & \text { Health }\end{array}$ \\
\hline
\end{tabular}

Source: Compiled after UNEP $(2012,16,18$ \& 20)

The thematic measuring aspects are further sub-divided into indicators (UNEP 2012b). For example, indicators on climate change include measuring carbon emissions, renewable energy (share of power supply) and energy consumption. Green investment indicators include research and development, and environmental goods and services sector investment in US\$ per year. Green skills training indicators cover training expenditure in US\$ per year and percentage of GDP and number of people trained measured as persons per year. One critical aspect identified under the green economy readiness conceptual framework is capacity. The OECD (2012b) identifies a five-step conceptual framework (see Figure 4) that is required to develop green economy capacity. Such a process involves working with all key stakeholders to come up with a shared national agenda in developing policies and take investment decisions. The OECD sees capacity development as a pre- condition for green growth engagement, stressing that such capacity development must take place at three levels: governance (policy), organisational and individual. 


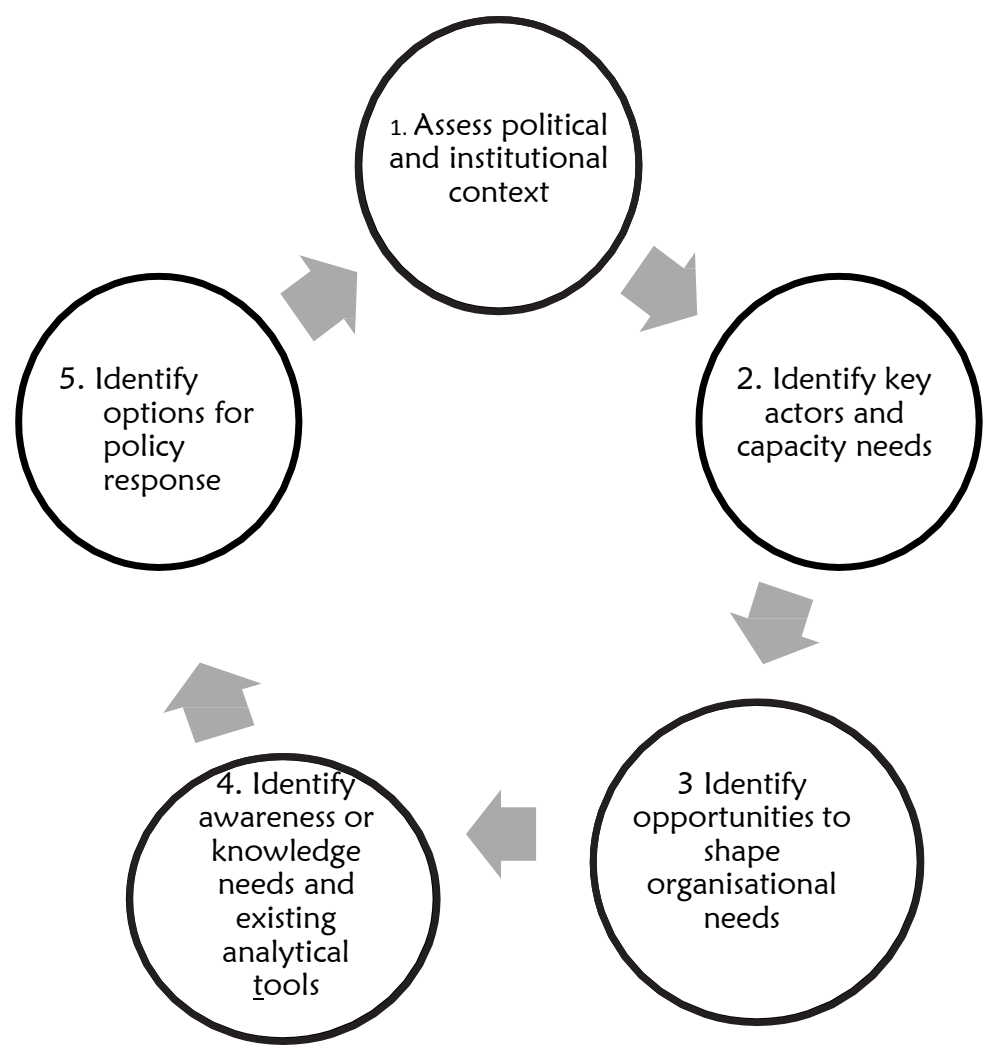


Figure 4: Framework for enhancing green economy capacity Source:

Author, after the OECD $(2012,29)$

At each level, overall capacity development objectives are set. The development of adequate and appropriate regulatory green growth regimes (including the rule of law and property rights as well as improvement in inter-institutional coordination and collaboration) must happen at governance level. At the organisational level, the key activity is the development of organisational performance and green growth management capabilities. Issues such as improved understanding of environment-growth- development linkages, the development of technical skills and support for long-term commitment all fall under individual capacity development (OECD 2012b). Overall, to be most effective, green economy capacity development should be mainstreamed into the national development planning process, and key influential line ministries and departments (finance, economic planning, trade and industry, national treasury). This does not necessarily negate the need to have all line ministries and other actors be green economy ready. Given the above discussions, this author proposes a combination of parameters that make up a framework for assessing green economy readiness. The framework may be applied at various levels of government including national (as is the case here), provincial, local and (with minor modifications) even the business sectors (Table 2 ). 
Table 2: Green economy readiness stages

\begin{tabular}{|c|c|c|}
\hline Stage & Parameter & Key components \\
\hline 1 & $\begin{array}{l}\text { High-level } \\
\text { commitment and } \\
\text { championing }\end{array}$ & $\begin{array}{l}\text { - Head of state/government proclaims political and/or } \\
\text { government commitment to green economy transition agenda. } \\
\text { At every stage of green economy readiness engagement, there } \\
\text { should be a deliberate strategy to identify and nurture } \\
\text { champions. } \\
\text { Call for a national green economy summit to raise awareness } \\
\text { and debate understanding on the concept to have buy-in. }\end{array}$ \\
\hline 2 & $\begin{array}{l}\text { Institutional set-up } \\
\text { and capacity } \\
\text { development }\end{array}$ & $\begin{array}{l}\text { - In consultation with other line ministries/departments, the head } \\
\text { of state must identify and designate a lead implementing } \\
\text { ministry/ department. Effort must be made to bring all line } \\
\text { ministries/ departments to a common understanding of the } \\
\text { national green economy agenda. } \\
\text { Responsible entities to establish institutions and/or re-align } \\
\text { existing ones as per the provisions of the developed legislation. } \\
\text { - Responsible authorities to build individual and institutional } \\
\text { green economy capacity in preparation for programme and } \\
\text { project implementation, monitoring and evaluation } \\
\text { - Setting up of green economy knowledge management hubs. }\end{array}$ \\
\hline 3 & Finance & $\begin{array}{l}\text { National government to seek green economy readiness funds } \\
\text { and seek assistance from local partners and free external grants, } \\
\text { if available. } \\
\text { Mechanisms for disbursing the available green funds are in place } \\
\text { and adhered to. }\end{array}$ \\
\hline 4 & $\begin{array}{l}\text { Green economy } \\
\text { policy (including } \\
\text { legislation) } \\
\text { development }\end{array}$ & $\begin{array}{l}\text { - Stakeholders to check status of existing green economy policies } \\
\text { in preparation of green economy mainstreaming. } \\
\text { Responsible line ministries to draw up new and/or amend } \\
\text { existing national legislation and mainstream green economy } \\
\text { into such legislation. }\end{array}$ \\
\hline 5 & $\begin{array}{l}\text { Research and } \\
\text { development, } \\
\text { technology and } \\
\text { innovation and } \\
\text { intellectual } \\
\text { property rights }\end{array}$ & $\begin{array}{l}\text { - Institutions and individuals to embark on continuous research, } \\
\text { development, technology, innovation and registering of green } \\
\text { technology intellectual property rights. } \\
\text { - } \quad \text { Local technology deployment and reverse engineering. } \\
\text { - Indigenous and local knowledge systems are branded with } \\
\text { scientific knowledge systems. }\end{array}$ \\
\hline 6 & $\begin{array}{l}\text { Programmes and } \\
\text { projects: design, } \\
\text { implementation, } \\
\text { monitoring and } \\
\text { evaluation }\end{array}$ & $\begin{array}{l}\text { - All ministries/departments and sectors at all spheres of } \\
\text { government and the private sector to come up with feasible } \\
\text { green economy strategies, investment and action } \\
\text { (implementation) plans specifying, especially big and quick } \\
\text { wins. } \\
\text { Monitoring and evaluation mechanisms are in place, clear and } \\
\text { being implemented. }\end{array}$ \\
\hline
\end{tabular}


It is impossible to do a full audit of green economy readiness for the whole South Africa in a single article, which necessitates a look at all spheres of government, as well as organised industry and labour. Hence this work focuses on the national sphere of government. The other spheres (provincial and local government) are subject to further future research. Specialised sectors such as industry and higher education are also targeted for full future research papers. The key findings are presented in the sub-sections which follow.

\section{High-level commitment and stakeholder buy-in}

As indicated earlier, readiness is not an event but a process. At the national level, the head of state and government, President Jacob Zuma, has made it clear that the country must be on a green economy pathway. His first commitment was made during the Copenhagen Climate Summit in 2009, amidst a global financial crisis. In his speech at the end of the summit, Zuma committed South Africa to a path that would see emissions reduced by 34 per cent by 2020 and by 42 per cent by 2025 , on condition that funding and technological support be provided mainly by international mechanisms (Zuma 2009). The Green Economy Summit of May 2010 and the UN Framework Convention on Climate Change's Seventeenth Session Conference of the Parties (COP17), hosted by South Africa in Durban (2011), were highlighted among other high-level commitments to green economy transition by South Africa.

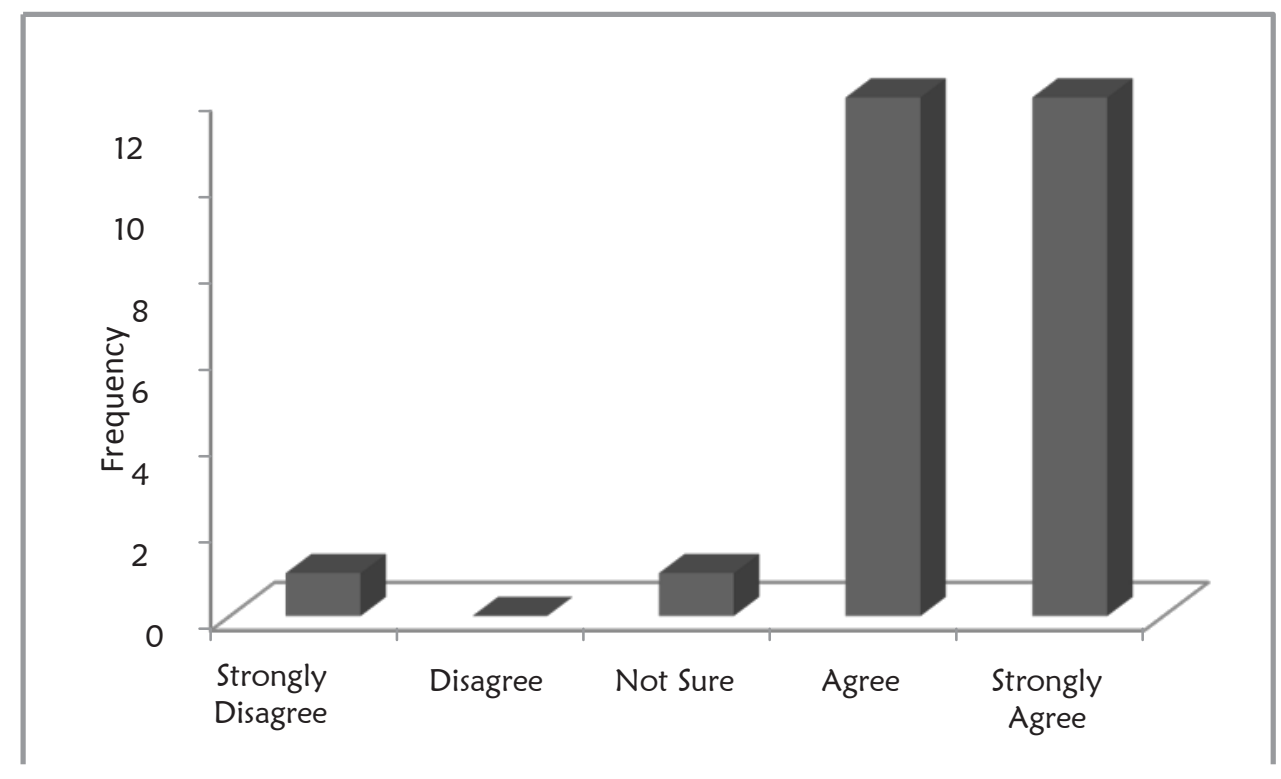

Figure 5: Experts' perceptions of high-level commitment Source:

Author (based on experts' survey, $n=26$ ) 
From the experts' survey (see Figure 5) there is no doubt that the South African government has made a high-level commitment at the level of pronouncements, in policy statements and in various key speeches concerning policy shifts towards green economy transition. Of the 26 experts who responded to the survey, 24 indicated that they either agree (12 respondents) or strongly agree (12) that the South African government has committed itself to the green economy agenda. Only a single respondent indicated that $s$ /he strongly disagrees with the proposition, while one was not sure. The experts also revealed that in their view, there has been excellent stakeholder buy-in (Figure 6). Of the 26 experts polled, nine agreed there has been key stakeholder buy-in, while 12 strongly agreed with the statement.

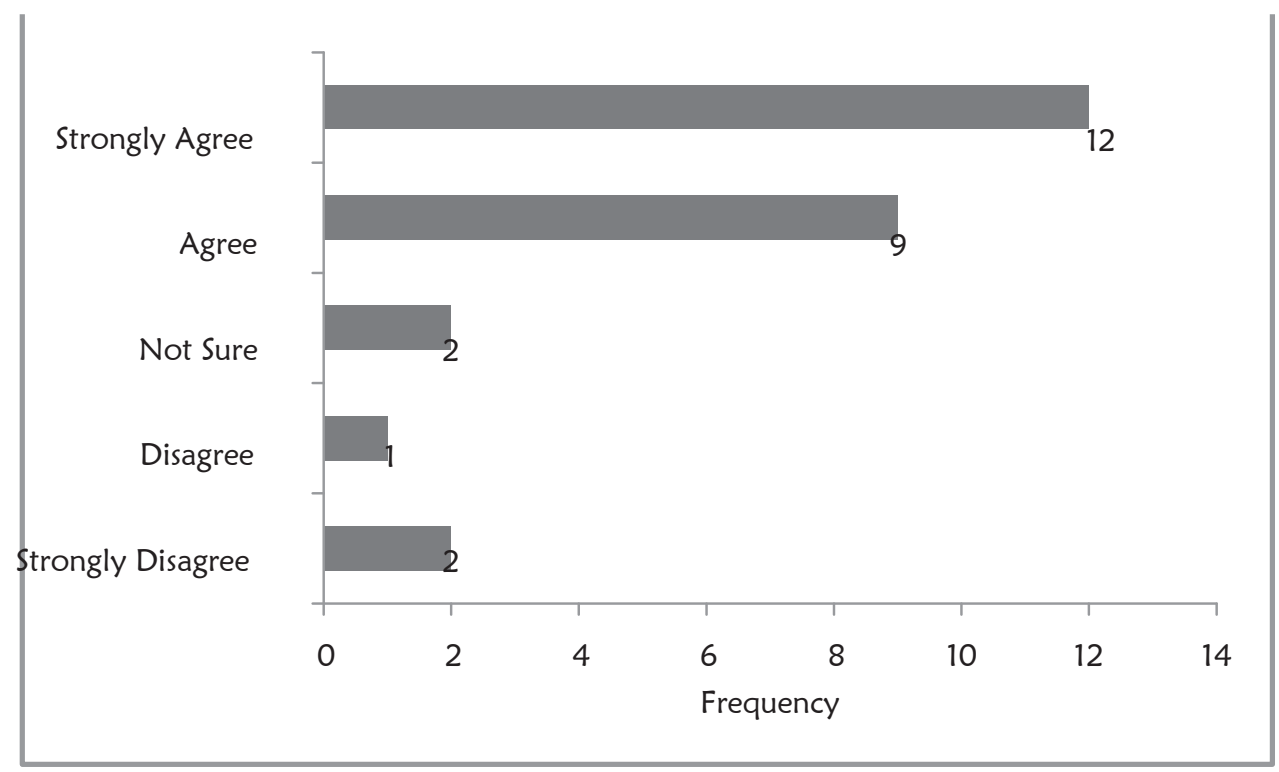

Figure 6: Perceptions on key stakeholder engagement and buy-in Source:

Author (based on experts' survey, $\mathrm{n}=26$ )

A green economy framework for South Africa emerged during the May 2010 Green Economy Summit, held under the theme 'Towards a resource-efficient, low-carbon and pro-employment growth path' (DEA 2010, 6). From the summit, the following green economy focus areas were identified: sustainable consumption and production; policy, fiscal and regulatory frameworks; financing; green buildings and built environments; sustainable transport; clean energy and energy efficiency; green cities and towns; resource conservation and management; sustainable waste management; and agriculture, food production and water management. Over the years, the framework has been refined to address the issues outlined in Figure 7. 


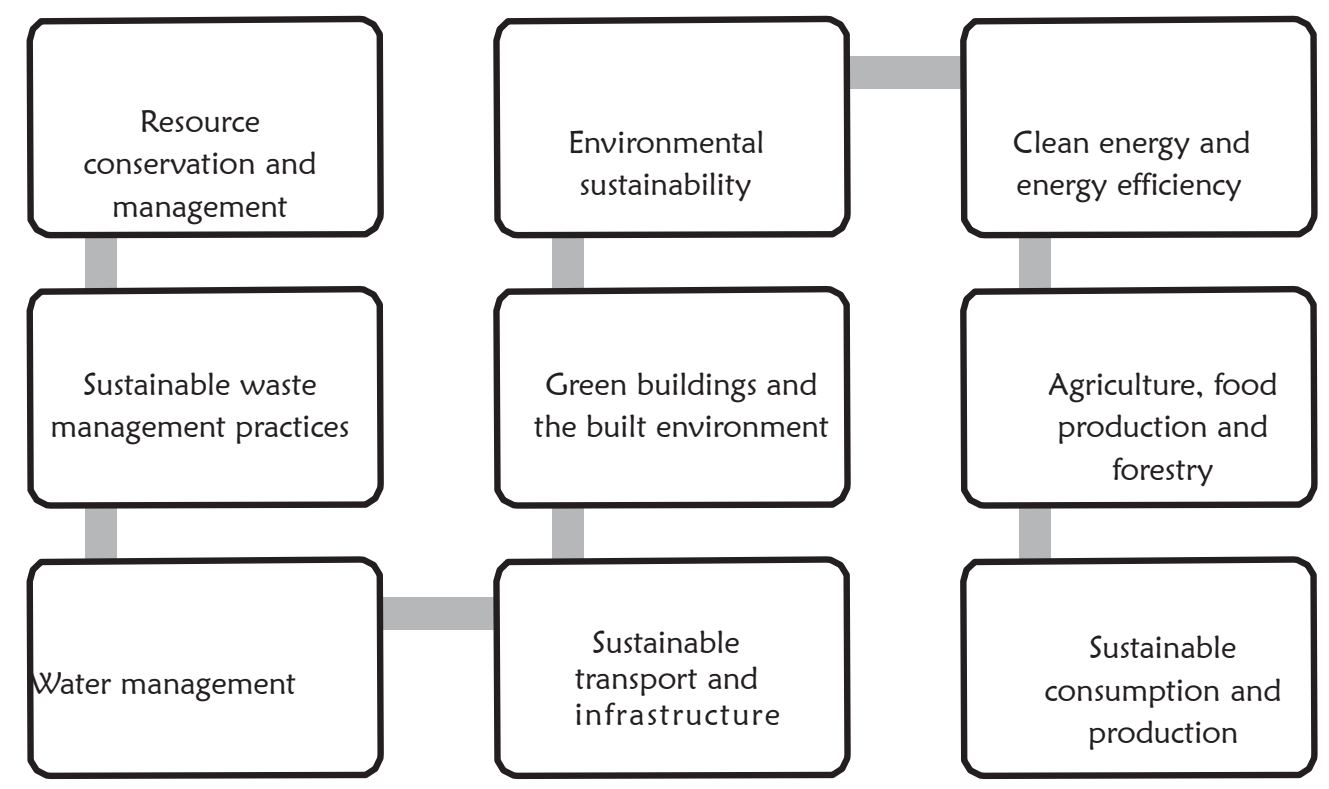


Figure 7: Green economy model for South Africa Source:

Author, based on DEA (2012)

Since the inception of the South African green economy model, programmes like payment for ecosystems services, water harvesting, effluent management, municipal metering, waste beneficiation (waste to energy and recycling), off-grid options, solar water heating, non-motorised transport and sustainable transport, are being pursued rigorously. Cross-cutting aspects in the model cover fiscal mechanisms, green cities and towns and capacity building (DEA 2012). Following this path, South Africa's message to the Rio+20 Summit highlighted that sustainable development remains the key theme, and green economy one of the many practical components for implementing sustainable development. Each country needs to define its final path to sustainability, while governments must revisit and be informed by the 1992 Rio Declaration on Environment and Development.

\section{Finance}

Finance is one of the pillars of green economy readiness in South Africa. The Green Fund, established in 2012 (SAGF 2013a) and administered jointly through the Development Bank of Southern Africa (DBSA) and the DEA, topped the list on this item. Other financing mechanisms include the Industrial Development Corporation (IDC) and funds such as the DBSA Dryland, and international funds to the South African National Biodiversity Institute (SANBI). The perceptions of the 26 experts on financial readiness are shown in Figure 8. Nineteen of the 26 respondents concurred that the government has made inroads in terms of setting up green economy funding mechanisms. 


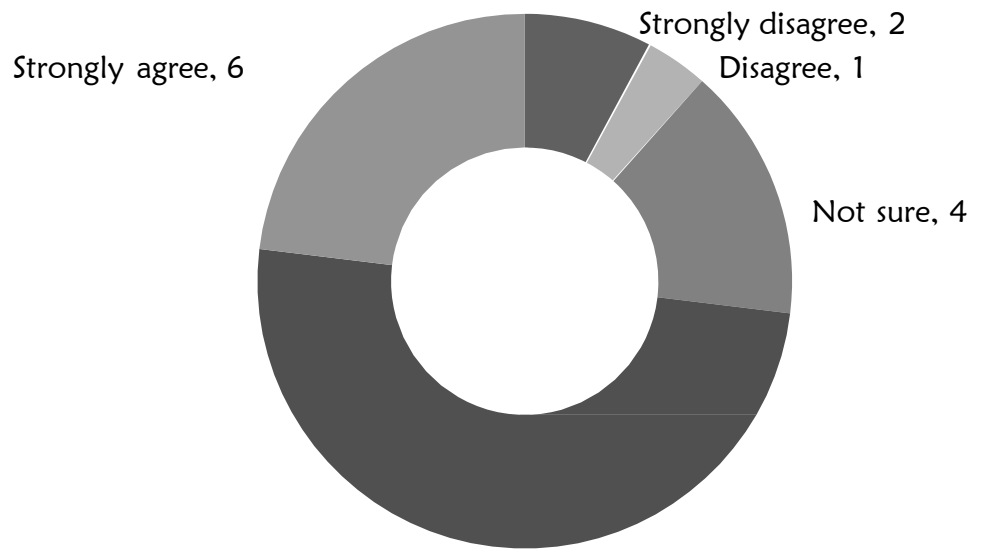

Agree, 13

Figure 8: Perceptions on financial readiness

Source: Author (based on experts' survey, $n=26$ )

\section{The policy development space}

A number of policies are already in place, as identified by the respondents. Some policies are devoted strictly to addressing green economy issues, while others only make reference to them. The policies include the National Development Plan (National Planning Commission 2012); the New Growth Path (Economic Development Department [EDD] 2010); the Green Economy Accord (EDD 2011); the Integrated Resource Plan (DTI 2011); the National Strategy for Sustainable Development and Action Plan (DEA 2011a); the Medium-Term Strategic Framework 2009-2014 (National Treasury 2009); the National Climate Change Response White Paper (DEA 2011b); the Green Economy Model (DEA 2012); the National Skills Development Strategy III (Department of Higher Education and Training [DHET] 2011) and many more. Since there is not adequate space to discuss all policies referring to green economy transition in South Africa, only a few will be discussed in brief. The experts' perceptions on legislation are shown in Figure 9. Eighteen of the 26 respondents either agreed or strongly agreed that green economy policies were in place in South Africa. 


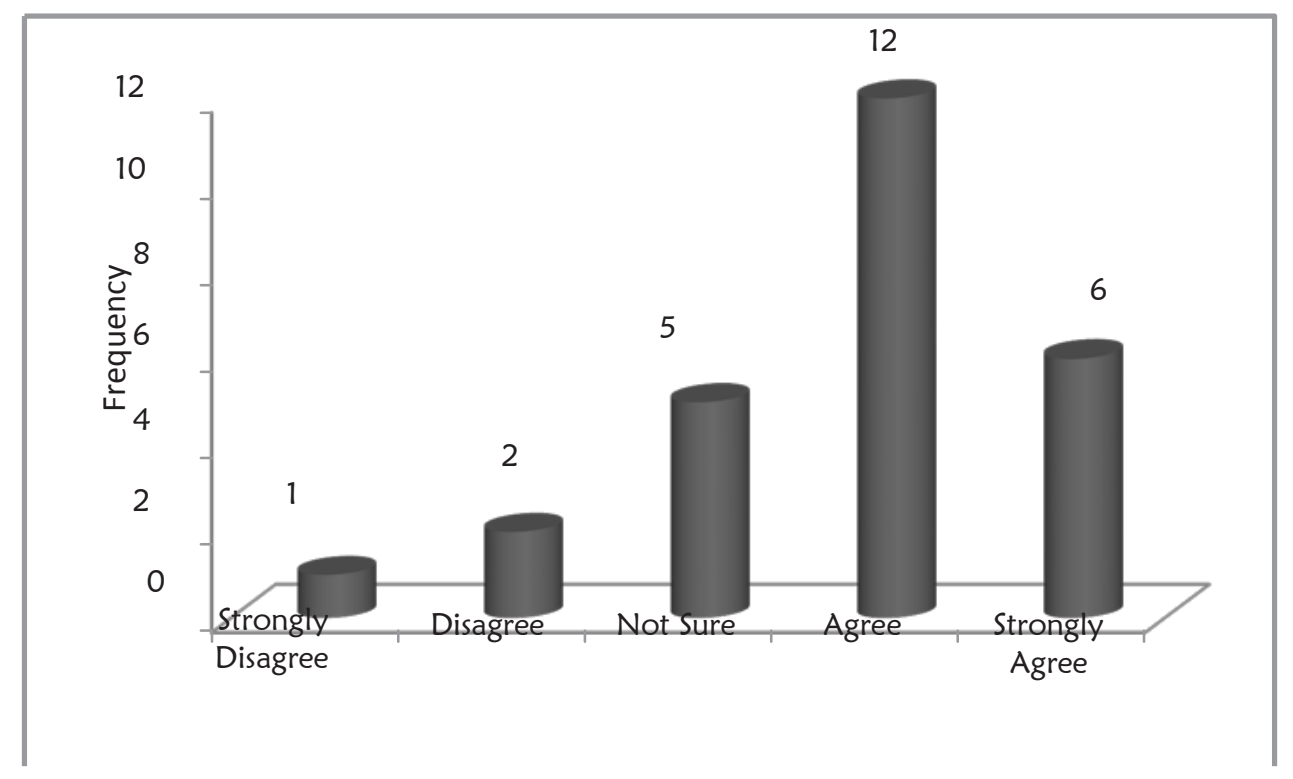

Figure 9: Perceptions on green economy legislation readiness Source:

Author (based on experts' survey, $n=26$ )

The New Growth Path (EDD 2010) includes the green economy as a key sector for economic growth and employment generation, among the six sectors specified. The National Development Plan (2012) devotes a full chapter to addressing green economy issues (National Planning Commission 2012); the National Skills Development Strategy III (DHET 2011) lists the need to develop skills in support of the green economy as a national priority; while the Integrated Youth Development Strategy for South Africa (National Youth Development Agency [NYDA] 2011) identifies the need to establish a Green Economy Training Academy to focus on short learning programmes. The academy aims to train 2000 youth annually through partnerships with municipalities, the DEA and other stakeholders. The annual budget will be in the region of R50 million. The NYDA also spelt out the nature of green economy projects it envisages to cover: air quality management and climate change; renewable energy and energy efficiency; waste management; and water and wastewater management. Such projects will cost up to R1.5 billion across all provinces, with nine small to medium enterprises (SMEs) established per each green economy sector and a total of 180000 jobs created over a period of five years.

A report by the Economic Sector and Employment Cluster on the Industrial Policy Action Plan Phase II (DTI 2011) shows that work on green industries is progressing well. The revision of building standards (now requiring higher levels of energy efficiency and compulsory solar water heater installation in new buildings) has been finalised. The South African Bureau of Standards (SABS) completed work on standards for solar water heaters; wind energy turbines; energy-efficient lighting and other applications; 
electric batteries and alternative fuel vehicles; and the cogeneration of electricity and biofuels. South Africa should be commended for drawing up draft legislation to address the transition to a green economy. However, despite swift movement in this field, challenges have arisen exactly because of the volumes of legislation being turned out. Nhamo and Bimha (2011) and Nhamo and Ho (2011) highlight difficulties pertaining to concepts and definitions on renewable energy and energy efficiency in the legislation. Several definitions on these terms can be found across policies and related acts. The government also made an about-turn concerning the Renewable Feed-in-Tariff Regulations of 2009 (DoE 2009), by changing the set-up from feed-in tariff to bidding in 2010 (Polycarp et al. 2013). Regardless of these setbacks, the South African government has made significant progress towards meeting its $10000 \mathrm{GWH}$ of renewable energy target, set for 2014 (DME 2003).

High-level political commitment is, however, questioned given the government's development trajectory that allows its power utility, Eskom, to continue building coal- fired power stations. In addition, a war of words has erupted between government and key labour movements on the NDP. In March 2013, the General Secretary of the National Union of Metalworkers of South Africa (Numsa), Irvin Jim, accused the government of using the Democratic Alliance's (an opposition political party) economic policies to inform the NDP (Sapa 2013). This position has been supported (see Bauer 2013) by the largest association of labour movements in the country, the Congress of South African Trade Unions (Cosatu). Cosatu's General Secretary, Zwelenzima Vavi, declared that the NDP merely recycled ideas from the abandoned Growth, Employment and Redistribution (Gear) plan that the government pursued from 1996. Vavi indicated that Cosatu would not be supporting the NDP - a position which has irked the ruling party and government, resulting in President Zuma reacting angrily to statements made by the labour movements. Zuma indicated that the NDP had been debated adequately during two ANC policy conferences in June and December 2012, and questioned whether delegates attending those sessions had been sleeping on duty (City Press 2013). The report further highlighted Zuma's call for reason when those in influential positions comment on government programmes.

\section{Institutional set-up and capacity development}

The space concerning the identification of a lead implementation agency is complex. Although the DEA emerged as the lead implementation agency, many other departments were also highlighted, including the Department of Economic Development, the National Treasury, the IDC under the DTI, the Department of Science and Technology (DST), the National Planning Commission, the DBSA, DEA's SANBI and the DST's Council for Scientific and Industrial Research (CSIR). The 26 experts' views are shown in Figure 10. 


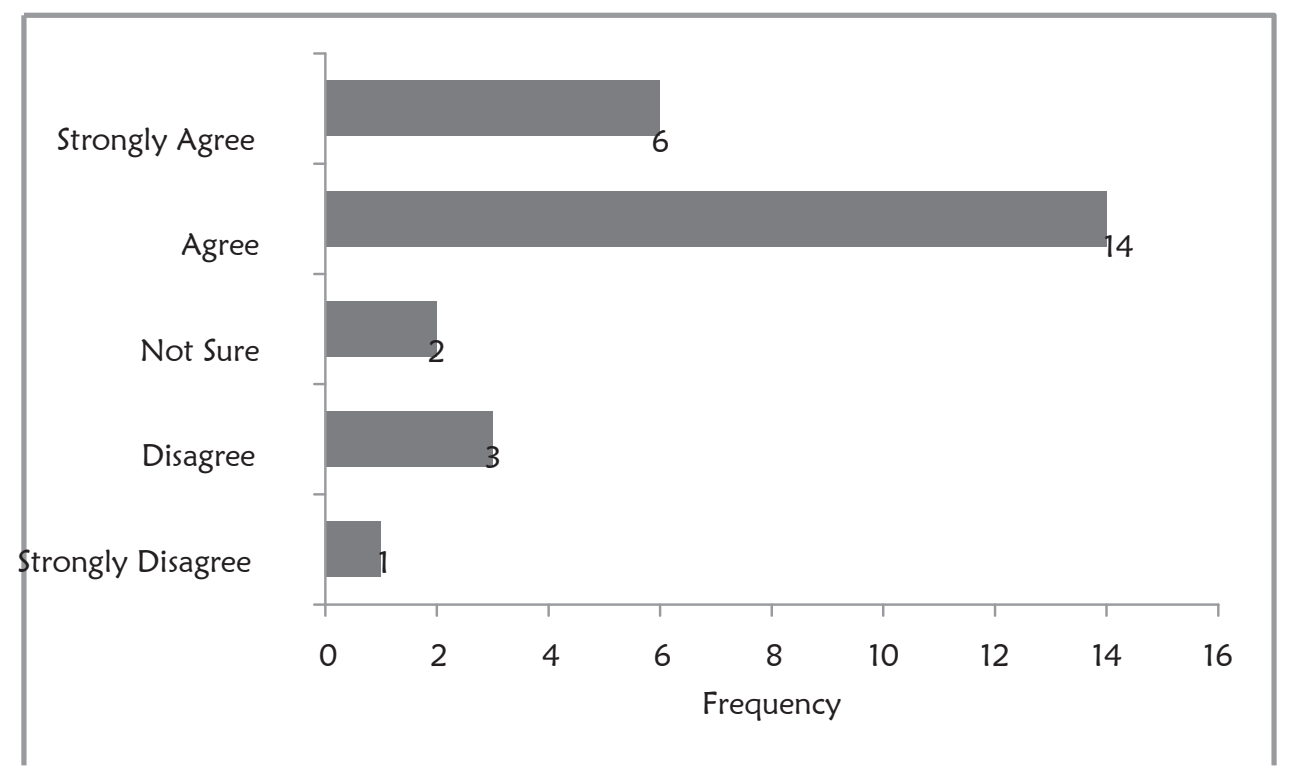

Figure 10: Identification of lead implementation agency

Source: Author (based on experts' survey, $n=26$ )

In their work on governance of climate change in South Africa, Giordano et al. (2011) indentify challenges associated with horizontal and vertical coordination. The authors start from an understanding that as a complex and cross-cutting issue, addressing climate change may not be left to a single government department. To this end, effective and efficient mitigation and adaptation intervention measures require buy-in from across various spheres of government. Three key challenges were observed: views that climate change mainstreaming is a constraint to development priorities; agreeing on a definition of mainstreaming; and the highly fragmented general environmental policy space which hosts climate change. In terms of horizontal coordination, 32 national departments were identified with at least 19 directly or indirectly involved with climate change mainstreaming (ibid.). However, apart from the DEA, none of the national sector departments were seen to take climate change mainstreaming as an operational priority. Although the National Climate Change Response White Paper enshrines two key coordinating institutions, the Inter- ministerial Committee on Climate change (IMCCC) and the Forum of South African Directors-General (FOSAD), weaknesses associated with the ability and willingness of these institutions to implement policies are still inherent (ibid.). Other institutions specified in the White Paper (DEA 2011b) are: the Intergovernmental Committee on Climate change (ICCCC); the National Disaster Management Council; the South African Local Government Association (SALGA); the Ministerial Political Forum (MINMEC); the Outcome 10 Delivery Forum (MITECH); the National Committee on Climate Change (NCCC); and the National Economic Development and Labour Council 
(NEDLAC). Business and industry, civil society as well as academia and scientists are included under these institutions. Vertical coordination relates to the existing spheres of government (including national, provincial and local). Local government can be divided into three spheres: metropolitans, district and local municipalities. To streamline vertical coordination, the National Climate Change Response White Paper (DEA 2011b) re-instituted the existing ICCCC and also tasked SALCA with the responsibility (Giordano et al. 2011). The DBSA, DEA, IDC, National Planning Commission, Department of Economic Development, the NPC and National Treasury were cited among key institutions driving the green economy in South Africa, by the experts polled. The identification of so many departments is not surprising, given the cross-cutting nature of green economy issues - especially when climate change forms part of the mix. Polycarp et al. $(2013,25)$ identify a straightforward gap pertaining to the local institutional set-up within the context of the green economy. The authors focused on the development of renewable energy, and concluded that there is 'lack of clear and appropriate institutional mandates'. This same observation was made by Nhamo and Bimha (2011) and Nhamo and Ho (2011).

The message that emerged from the experts regarding institutional set-up readiness was inconclusive. This perception holds water, given that while the existing institutions are doing their best, the administration of the Green Fund (hosted by the DBSA and the DEA) has been problematic, with project proponents waiting for long periods to hear the outcome of the adjudication process. In fact, 590 project proposals with a value of R10.9 billion were received (SAGF 2013b) following the first call for expressions of interest during the R800 million bidding window. Later, the DBSA had to place a tender call for would-be adjudicators of the proposals. To date, no further information has become available on this issue. Although the perceptions on institutional and individual capacity were inconclusive, the South African government has invested in strengthening these capacities. Virtually all key sector departments with significant climate change and green economy mandates have instituted directorates dealing with climate change. Information retrieved and analysed from the South African government online (www.gov.za), leading to the relevant departments, clearly confirm that inroad are being made. The DEA has the widest institutional and individual capacity, with a full branch comprising five chief directorates dedicated to address different climate change and air quality aspects. Another directorate on Sustainable Development and Green Economy falls outside the five climate change and air quality chief directorates. Figure 11 shows the orientation of the four chief directorates dealing with climate change in the DEA. 


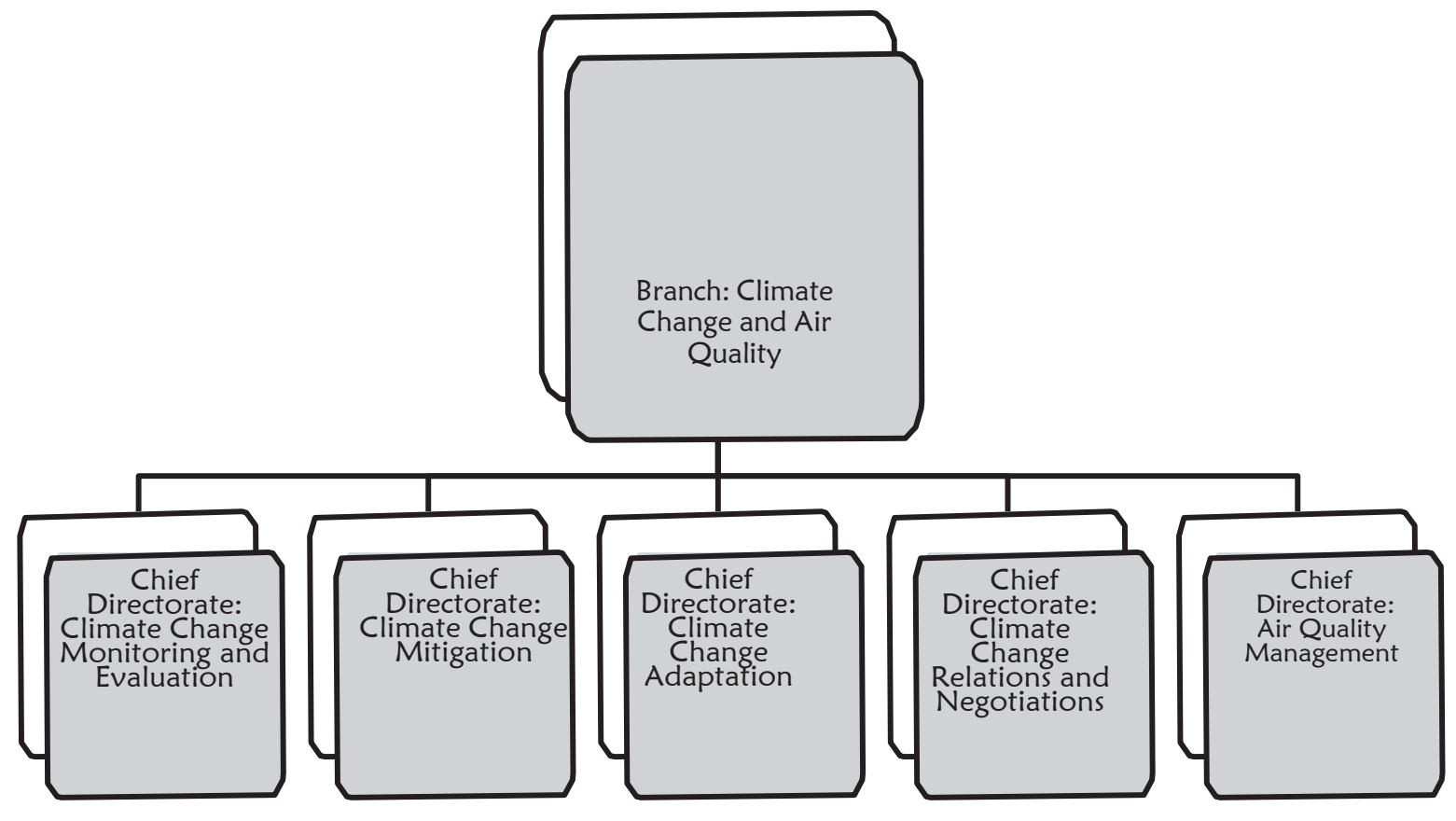

Figure 11: Institutional arrangement for climate change in the DEA

Source: Author (based on www.gov.za, accessed 10 April 2013)

Other key line departments with significant mandates on climate change have existing directorates: the Department of Water Affairs has a directorate on Climate Change; while the Department of Agriculture and Forestry has a directorate on Climate Change and Disaster Management. The DTI has an Industrial Development Policy Division that develops industrial policy action plans (IPAPs). The Department of Cooperative Governance and Traditional Affairs has a Disaster Management Centre. Under the Department of Science and Technology there is a Climate Change and Biodiversity unit. In the Department of Public Works there is an Environment Cluster under the Expanded Public Works Programme Phase II. Eskom and Sasol, top carbon emitters resorting under the Department of Public Enterprises, have huge climate change management programmes. The National Treasury has an Economic Policy Division that addresses issues pertaining to carbon and other green taxes. The division also undertakes environmental law reforms and feeds into the budget system which, over the past four years, has been advocating budgetary support for South Africa's green economy transition. The EDD has a policy unit, as does the IDC. The New Growth Path and the Green Economy Accord are part of the policy proclamations that emerged from the EDD. The IDC has a full business unit dealing with green industries. The Department of International Relations and Cooperation hosts a directorate on Climate Change and Pollution. The Designated National Authority, tasked with approving the Clean Development Mechanism (CDM) projects under the Kyoto Protocol, sits with the Department of Energy. In addition, the Department of Energy has a full branch dealing with clean and renewable energy.

Institutions dealing with climate change (in particular, sustainable development and green economy) have their challenges. As noted earlier, horizontal coordination challenges remain. Chances are that duplication may lead to conflict. Apart from regulated mainstreaming, the arrangement calls for improved individual and interpersonal relations. 


\section{Programmes and projects}

The last set of parameters in assessing green economy readiness deals with programmes and projects. Among the projects that show commitment to South Africa's green economy readiness are the following: National Solar Water Heating initiated in 2009; a series of atlases completed in 2010 which include Wind, Risk and Vulnerability, the Geological atlas for carbon capture and storage and the Solar atlas. Solar Park in the Northern Cape is another great initiative, while existing industrial development zones such as Coega and East London in the Eastern Cape are being promoted for green economy industries and projects. The national electricity grid links the hinterlands, making it possible to link up with renewable energy initiatives across the country.

\section{Action points into the future}

Based on the information presented here, this section focuses on presenting suggestions that could enhance green economy readiness in South Africa. A number of such suggestions focus on the continued domestication of our understanding of a 'green economy'; weak individual capacity; funding dilemmas; a proliferation of policies; matching national to global interests on green economy; and the role of higher (and further) education. Each key observation and action point is briefly presented hereunder.

- Continued domestication of our understanding of a green economy: Although efforts have been made (and are being made) to reach a single rallying point concerning green economy readiness, some local stakeholders still have a vague understanding of the concept. The notion of a green economy as a means to an end and/or as an end in itself, needs clarification. To fully oil the green economy readiness machine in this country, the government needs to embark on an offensive to educate the masses and raise awareness by decoding this seemingly scientific concept to levels where an ordinary citizen can relate to and identify with the vision. Multiple media platforms (television, print, arts and drama) could be used for this purpose, including the use of all 11 official languages.

- Weak individual capacity: Green economy is a relatively new concept, popularised through the May 2010 Green Economy Summit, attended by the president, several ministers, businesspeople, NGOs, labour, academia, and the who's who of the green economy in South Africa. Given that only three years have passed and that key green economy policies are barely two years old, individual capacity in institutions driving the agenda is still very weak. Hence, more financial and infrastructure resources are needed. Certain new national departments, like Economic Development, only came on board in 2009, and are still finding their feet. Evidence of limited capacity was drawn from the slow adjudication processes following the first and the second bidding rounds for the Green Fund. In addition, directorates across all spheres of government dealing with green economy issues are still new, and their capacity needs to be enhanced. 
- $\quad$ Funding dilemmas: Money is never in excess supply. Bids for the Independent Power Producers and the Green Fund far surpassed the allocated funds. The second bidding window for the Green Fund attracted proposals amounting close to R10.9 billion against an allocation of R800 million over three years. There is, therefore, an urgent need for the National Treasury and other funding institutions and mechanisms to put more funding on the table, with a view to upscaling the green economy agenda.

- Proliferation of policies: This work revealed that a cocktail, if not a policy 'jam', exists in the space covering climate change, sustainable development and green economy. Most policies were developed during 2010-2012. Such a landscape brings volumes of reading to officers and political heads in various spheres of government - a daunting challenge. Most worrying is the absence of an acceptable national policy document on the green economy. Will the national holding policy, which everyone is rallying around, be the National Development Plan, the National Climate Change Response White Paper, the New Growth Path, the Green Economy Accord or the National Sustainable Development Strategy III? Nobody has a straightforward answer on this one, and more work is required.

- Matching national to global interests on green economy: National green economy interests must continuously be aligned with global interests in a country like South Africa, which is a member of major economic blocks like the Group of 20 (G20) industrialised economies and the BRICS economic bloc. Currently, the global tide is moving along with green economy as a means of attaining sustainable development, therefore South Africa is conforming. What next? This is an open question. Overall, South Africans are advised to continue searching for synergies between and among seemingly old and new development conceptualisations. Hence, a space exists for South Africa to maintain green economy readiness while checkmating developments on a global platform and searching for pioneering operating spaces within emerging development paradigms.

- Higher (including further) education: This sector has seemingly not 'come to the party' full time. Although there are flashes of movement here and there, overall, the sector remains grounded in old curricula, thereby starving organisations of much- needed, specialised green economy skills. As a key driver of the green economy readiness agenda, curricula that address (on an equal footing at least) the adaptation and mitigation agenda would be a minimum requirement for any green economy transition. The lack of skills (reflective) of the higher education sector in this country is well articulated in a number of policies, as discussed earlier.

\section{Conclusions}

This article teased out aspects of green economy readiness in South Africa. Although considered a simple concept, 'readiness' is far from it. The literature review assisted in determining generic and specific green economy readiness frameworks and related parameters. From Korea to Rwanda, green economy readiness examples emerged. 
Drawing from a wide literature base on green economy readiness, a green economy readiness framework comprising six key parameters was drawn up. Data from a small reconnaissance survey, for a quick snapshot of the perceptions of 26 carefully selected green economy experts, were analysed and compared to further desktop work on South Africa. This author concludes that although South Africa has made significant progress in putting up the necessary pillars to enhance its transition to a green economy and address issues relating to sustainable development and poverty eradication, more work needs to be done. This includes increased budget allocations for green economy projects; improving institutional and individual capacity; better horizontal and vertical coordination and mainstreaming of the green economy agenda; and increasing knowledge management capacity. Lastly, the bias towards climate change mitigation, compared to the climate change adaptation agenda, is evident across many South African policies - just as it is at global level. Moving forward, as the South African government prepares to enhance its green economy readiness, the fast-tracking of the adaptation agenda is highlighted in order to balance the green economy readiness equation.

\section{Acknowledgement}

The author thanks Exxaro Resources Limited for sponsoring the Chair in Business and Climate Change run under Unisa's Institute for Corporate Citizenship. 


\section{REFERENCES}

African Development Bank (AfDB). 2012. Facilitating green growth in Africa: Perspectives from the African Development Bank. Tunis: African Development Bank.

African Union Commission. 2011. The green economy in Africa: Setting up the political context. Addis Ababa: African Union Commission.

Bauer, N. 2013. Cosatu's Vavi condemns national development plan. http://mg.co.za/

article/2013-03-12-cosatu-condemns-national-development-plan

(accessed 23 April 2013).

Cadogan-Cowper, A. and T. Johnson. 2011. Measuring the green economy. Adelaide: Australian Bureau of Statistics.

City Press. 2013. National Plan the new Gear? http://www.citypress.co.za/politics/national- planthe-new-gear/ (accessed 23 April 2013).

Climate and Development Knowledge Network (CDKN). 2011. Green growth: Implications for development planning. London: CDKN.

Cosbey, A. and P. Wooders. 2011. Border carbon adjustments: What risk for South African exporters? London: International Institute for Sustainable Development.

Deloitte, 2012. The rewards of a green economy: Cultivating operational value through sustainability partnerships. London: Deloitte.

Department of Environmental Affairs (DEA). 2010. Green economy summit report. Pretoria: DEA.

Department of Environmental Affairs. 2011a. National Strategy for Sustainable Development and Action Plan III. Pretoria: DEA.

Department of Environmental Affairs. 2011b. National Climate change Response White Paper. Pretoria: DEA.

Department of Environmental Affairs. 2012a. Draft South African Green Economy Model. Pretoria: DEA.

Department of Environmental Affairs. 2012b. South Africa's green economy initiatives: UNEP green economy webinar, May 2012. Pretoria: DEA.

Department of Higher Education and Training (DHET). 2011. National Skills Development Strategy III. Pretoria: DHET.

Department of Minerals and Energy (DME). 2003. White Paper on Renewable Energy. Pretoria: DME.

Department of Minerals and Energy. 2009. National Energy Efficiency Strategy of the Republic of South Africa. Pretoria: DME.

Department of Trade and Industry (DTI). 2010. The 2010/11-2012/13 Industrial Policy Action Plan (IPAP II). Pretoria: DTI. 
Dual Citizen. 2012. The 2012 Global Green Economy Index: An analytic tool measuring national green reputations and performance. London: Dual Citizen.

Economic Development Department (EDD). 2010. New Growth Path. Pretoria: EDD. Economic Development Department. 2011. Green Economy Accord. Pretoria: EDD.

Economist Intelligence Unit. 2011. Cleaning up - Australia's readiness for a low-carbon future: $A$ report from the Economist Intelligence Unit. London: Economist Intelligence Unit.

Ellis, K., A. Cambray and A. Lemma. 2013. Drivers and challenges for climate compatible development. London: Climate and Development Knowledge Network.

EM-DAT. 2013. EM-DAT: The OFDA/CRED International Disaster Database. www.emdat.be (accessed 6 April 2013).

Giordano, T., L. Hall, A. Gilder and M. Parramon. 2011. Governance of climate change in South Africa. Pretoria: DEA.

Gordhan, P. 2013. Budget speech. Pretoria: National Treasury.

Green Economy Coalition. 2011. The green economy pocketbook: The case for action. London: Green Economy Coalition.

International Chamber of Commerce (ICC). 2011. Ten conditions for a transition toward a green economy. Paris: ICC.

Kang, S.I., J. Oh and H. Kim. 2012. Korea's low-carbon green growth strategy. Paris: OECD.

Melendez-Otiz, R. 2011. Governance of international trade for green economy. Review of Policy Research 28(5): 479-485.

Najam, A. and H. Selin. 2011. Institutions for a green economy. Review of Policy Research 28(5): 451-457.

National Treasury. 2009. Medium-term Strategic Framework. Pretoria: National Treasury. National Treasury. 2010. Reducing greenhouse gas emissions: The carbon tax option. Pretoria:

National Treasury.

National Youth Development Agency (NYDA). 2011. Integrated Youth Development Strategy for South Africa. Pretoria: NYDA.

Nhamo, G. and A. Bimha. 2011. Energy efficiency in South Africa: Policy perspectives and path to lowcarbon growth. Ecosystems and sustainable development VIII, ed. Y. Villacampa and

C.A. Brebbia, 389-402. Southampton: WIT Press.

Nhamo, G. and S-Y. Ho. 2011. Renewable energy policy landscape in South Africa: Moving towards a low carbon economy. Energy and sustainability III, ed. Y. Villacampa, A.A. Mammoli and C.A. Brebbia, 265-278. Southampton: WIT Press.

Organisation for Economic Cooperation and Development (OECD). 2012a. Green growth and developing countries: A summary for policy makers. Paris: OECD. 
Organisation for Economic Cooperation and Development. 2012b. Green development: Enhancing capacity for environmental management and governance. Paris: OECD.

Polycarp, C., L. Brown and X. Fu-Bertaux. 2013. Mobilising climate investment: The role of international climate finance in creating readiness for scaled-up low carbon energy. Washington, DC: World Resources Institute.

Rauschmayer, F. and O. Lessmann. 2013. The capability approach and sustainability. Journal of Human Development and Capabilities: A Multi-Disciplinary Journal for People- Centered Development 14(1): 1-5.

Rwanda Ministry of Natural Resources. 2011. Green Growth and Climate Resilience National Strategy for Climate Change and Low Carbon Development. Kigali: MINIRENA.

South Africa Green Fund (SAGF). 2013a. Welcome to the Green Fund. http://www.sagreenfund. org.za/Pages/default.aspx (accessed 14 April 2013).

South Africa Green Fund. 2013b. Green Fund receives R10.9 billion worth of project applications.http://www.sagreenfund.org.za/Pages/Project\%20Applications.aspx (accessed 14 April 2013).

National Planning Commission. 2012. National Development Plan: Vision for 2030. Pretoria: National Planning Commission.

Sapa. 2013. ANC used DA's plan, says Numsa's Jim. http://mg.co.za/article/2013-03-07-ndp- wasdirectly-lifted-from-da-says-numsas-jim (accessed 23 April 2013).

Sen, A. 2013. The ends and means of sustainability. Journal of Human Development and Capabilities: A Multi-Disciplinary Journal for People-Centered Development14(1): 6-20. United Nations Environment Programme (UNEP). 2011. Towards a green economy: Pathways to sustainable development and poverty eradication - a synthesis for policy makers.

Nairobi: UNEP.

United Nations Environnent Programme. 2012a. A green economy in a blue economy: Synthesis report. Nairobi: UNEP.

United Nations Environment Programme. 2012b. Measuring progress towards an inclusive green economy. Nairobi: UNEP.

Wapner, P. 2011. Civil society and the emergent green economy. Review of Policy Research 28(5): 525-529.

Zuma, J. 2009. Address by President Jacob Zuma at the UN Climate Change Conference, Copenhagen, 18 December. Pretoria: The Presidency. 